Т.С. Головко ${ }^{1}$, М.Е. Яроцький ${ }^{2}$ О.А. Бакай${ }^{1}$ І.В. Яроцька ${ }^{3}$, Н.Ф. Лигирда ${ }^{1}$

\title{
Променева діагностика для оцінки локального поширення пухлини у хворих на рак шийки матки
}

\author{
${ }^{1}$ Національний інститут раку, Київ \\ ${ }^{2}$ ТОВ «Академічний медичний центр», Київ \\ ${ }^{3}$ Національна медична академія післядипломної освіти імені П.Л. Шупика, Київ \\ Одержано: 8.06.2020 \\ Прийнято до друку: 2.07.2020 \\ DOI: 10.32471/clinicaloncology.2663-466X.37-1.27094
}

\begin{abstract}
При верифікованому раку шийки матки (РШМ) основним завданням променевого дослідження є оцінка поширення пухлинного процесу, оскільки це докорінно впливає на вибір тактики лікування та прогноз захворювання. Метою дослідження було оптимізувати магнітно-резонансне дослідження для визначення місцевого поширення пухлинного процесу у пацієнтів з РШМ шляхом порівняння корисності різних послідовностей магнітно-резонансної томографії. Об'єкт і методи дослідження. 62 пацієнти з РШМ, які проходили обстеження і лікування в Національному інституті раку. Структура розподілу за стадіями TNM:

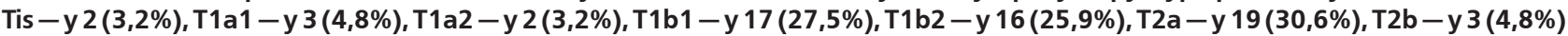
пацієнток. Морфологічна структура РШМ: у 54 (87,1\%) - плоскоклітинний рак, у 6 (9,7\%) - аденокарцинома, у 2 (3,2\%) - адено-плоскоклітинний рак. Усім хворим виконано оперативне видалення пухлини. 3 пацієнтки з РШМ Т1b2, 18 - 3 T2a і 3 з T2b отримали курс неоад'ювантної хіміотерапії. Пацієнткам проводили магнітно-резонансну томографію на томографі Philips (Intera) 1,5 Т із застосуванням контрастного підсилення та дифузійно-зваженої візуалізації (Diffusion-weighted imaging - DWI). Результати променевої оцінки поширення пухлинного процесу зіставлені з даними морфологічного дослідження. Результати. Визначена діагностична ефективність методів променевого дослідження для оцінки місцевого поширення пухлини у хворих на РШМ. Помилкове завищення ступеня розповсюдження пухлинного процесу було обумовлене інтенсивним накопиченням контрастної речовини тканинами навколо пухлини внаслідок реактивного запалення. Використання DVI дозволило зменшити кількість помилково позитивних результатів і значно підвищило ефективність магнітно-резонансної томографії $(p<0,05)$ : позитивна прогностична величина, чутливість, специфічність та точність становили 83,3; 90,9; 96,0 та 95,1\% відповідно. Висновки. Найбільш інформативною комбінацією для оцінки місцевого поширення пухлинного процесу у хворих з верифікованим PШМ є поєднання нативної послідовності з DWI, тому доцільно включати DWI в протокол магнітно-резонансного дослідження цих пацієнток.
\end{abstract}

Ключові слова: рак шийки матки; місцеве поширення пухлинного процесу; магнітно-резонансна томографія; контрастне підсилення; дифузійно-зважені зображення.

\section{ВСТУП}

Ракшийки матки (РШМ) - одназ найбільшпоширених форм злоякісних новоутворень жіночих статевих органів. В Україні, за даними Національного канцер-реєстру, у 2018 р.зареєстровано 4059 нових випадків розвитку РШМ, захворюваність становила 21,3 на 100 тис. населення. У структурі онкогінекологічної захворюваності жіночого населення України РШМ посідає 2-ге місце, а найвищі показники спостерігають у жінок репродуктивного віку [1]. При верифікованому РШМ основним завданням променевого дослідження є оцінка поширення пухлинного процесу, оскільки це докорінно впливає на вибір тактики лікування та прогноз захворювання [2, 3]. Планування лікування залежить від стадії хвороби. До 2018 р. стадіювання РШМ проводили переважно за клінічними даними, а результати променевих методів дослідження хоч і бралися до уваги, але не впливали на визначення стадії захворювання. 32018 р. згідно з останніми рекомендаціями Міжнародної федерації акушерів-гінекологів (Fédération Internationale de Gynécologie et d'Obstétrique - FIGO), результати радіологічної візуалізації враховуються при стадіюванні так само, як і клінічні дані і можуть змінювати стадію РШМ [4]. Першорядне значення для визначення стадії РШМ має наявність інвазії пухлини в параметрій та піхву [3].

Відомо, що серед методів діагностики магнітно-резонансна томографія (МРТ) $є$ найбільш інформативною при обстеженні 3 приводу РШМ, оскільки цей метод є більш чутливим у дослідженні м'яких тканин, ніж ультразвукове дослідження або комп'ютерна томографія [3, 5].

Послідовність Т2 (T2W) є еталонною для діагностики РШМ $[2,6]$. Оскільки вода дає інтенсивний сигнал на T2W, а в пухлинах багато вільної води, вони демонструють високу інтенсивність сигналу на МРТ T2W, контрастуючи зі стромою шийки матки з низькою інтенсивністю сигналу. Однак при деяких патологічних станах, наприклад запаленні та набряках, які також характеризуються підвищеним вмістом води та мають інтенсивний сигнал на T2W, високий власний контраст зображення може бути недостатнім для диференціальної діагностики патологічних змін $[5,7]$. Для посилення відмінностей між здоровими та патологічно зміненими тканинами застосовують контрастні речовини та дифузійно-зважену візуалізацію (Diffusion-weighted imaging - DWI) [3]. Парамагнітні контрастні молекули призводять до змін локальної напруженості поля i, таким чином, відображають мікросудинну мережу пухлин [8]. Як правило, інтенсивність сигналу при пухлині шийки матки є вищою, порівняно з такою в епітелії шийки матки та стромі, що допомагає диференціювати пухлини [3]. Однак використання контрастних речовин на основі гадолінію є неприйнятним у разі ниркової недостатності, алергії, вагітності, викликає безліч побічних ефектів $[9,10]$ та підвищує вартість обстеження. DWI відображає клітинну щільність. Сучасні дослідження показали, що використання DWI може бути корисним для онкологічної діагностики $[10,11]$.

\section{МЕТА ДОСЛІДЖЕННЯ}

Метою дослідження є оптимізація магнітно-резонансного дослідження для визначення місцевого поширення пухлинного процесу у пацієнтів з РШМ шляхом порівняння корисності різних послідовностей МРТ.

\section{ОБ 'ЄКТ І МЕТОДИ ДОСЛІДЖЕННЯ}

У дослідження було включено 62 пацієнтки з РШМ, які проходили лікування в Національному інституті раку (Київ, 
Україна). Розподіл за стадіями РШМ був таким: Tis $-2(3,2 \%)$, T1a1 - $3(4,8 \%)$, T1a2 - $2(3,2 \%)$, T1b1 - $17(27,5 \%)$, $\mathrm{T} 1 \mathrm{~b} 2-16(25,9 \%), \mathrm{T} 2 \mathrm{a}-19(30,6 \%), \mathrm{T} 2 \mathrm{~b}-3(4,8 \%)$ пацієнти. За морфологічною будовою: у $54(87,1 \%)$ випадках верифіковано плоскоклітинний рак, у 6 (9,7\%) випадках - аденокарциному, у $2(3,2 \%)$ випадках - адено-плоскоклітинний рак. Усім пацієнтам було проведено хірургічне видалення пухлини: шляхом конусовидної резекції - 1 пацієнтці, трахелектомії - 3 пацієнткам, гістеректомії - 58 пацієнткам. 3 пацієнтки з T1b2, 18 пацієнток з Т2а та 3 пацієнтки з Т2b проходили лікування за допомогою неоад'ювантної хіміотерапії.

Усіх пацієнтів обстежували за допомогою МРТ на томографі 1,5 Т. Протокол МРТ складався з послідовності Т2W турбо-спін-ехо (TR/TE 3000 мс/90 мс; розмір матриці $300 \times 261$; товщина зрізу 4,0 мм; зазор 1,0 мм) в сагітальній, корональній і аксіальній косій (перпендикулярно каналу шийки матки) послідовностях; турбо-спін-ехо T1W (TR/TE 559 мс/10 мс; розмір матриці $300 \times 261$; товщина зрізу 4,0 мм; зазор 1,0 мм) в аксіальній косій; постконтрастні T1W (після введення препаратів гадолінової кислоти в дозі 0,1 ммоль/кг маси тіла, сканування проводилося через 60 с після введення), DWI (TR/TE, 1389 мс/год 66 мс; розмір матриці $124 \times 124$; товщина зрізу 6 мм; зазор 1,5 мм; коефіцієнт $\mathrm{R}^{2}$; кут повороту $90^{\circ}$ ) в аксіальній площині зі значеннями $b=0 ; 400$ та 800 c/ мм² $^{2}$, карти ADC автоматично розраховувалися в серії $b=0 \mathrm{i} b=800 \mathrm{c} / \mathrm{Mm}^{2} \mathrm{DWI}$ за допомогою спеціального програмного забезпечення. Оцінку DWI проводили якісно відповідно до інтенсивності сигналу РШМ матки, що визначається візуальним порівнянням інтенсивності сигналу із сигналом міометрію. ADC (Apparent Diffusion Coefficient) - карти також були проаналізовані якісно. Період між закінченням курсу хіміотерапії та МРТ становив щонайменше 2 тиж.

Оцінювали наявність локальної пухлини, що поширилася в параметрій та піхву. Результати оцінки поширення пухлини в лімфатичні вузли не були включені в це дослідження. Проаналізовано 3 окремі набори зображень: лише нативні зображення, тільки з контрастуванням та DWI-послідовності (оцінювали разом з T2W). Результати передопераційної променевої діагностики порівнювали з операційними знахідками. Дані променевого дослідження оцінювали наступним чином:

- істинно позитивні - правильно виявлені та гістологічно підтверджені випадки інвазії РШМ за межі матки;

- істинно негативні - випадки правильного визначення відсутності місцевого поширення РШМ;

- хибнопозитивні випадки, коли інвазія РШМ, визначена під час магнітно-резонансного дослідження, не була підтверджена гістологічно. Також було включено випадки, коли інвазія була виявлена правильно в одному органі, але надмірно в іншому;

- хибнонегативні випадки, коли інвазія РШМ не була виявлена в магнітно-резонансному дослідженні, але потім була виявлена гістологічно.

Статистичний аналіз проводили за допомогою програмного забезпечення STATISTICA, версія 10.0 (портативна). Для
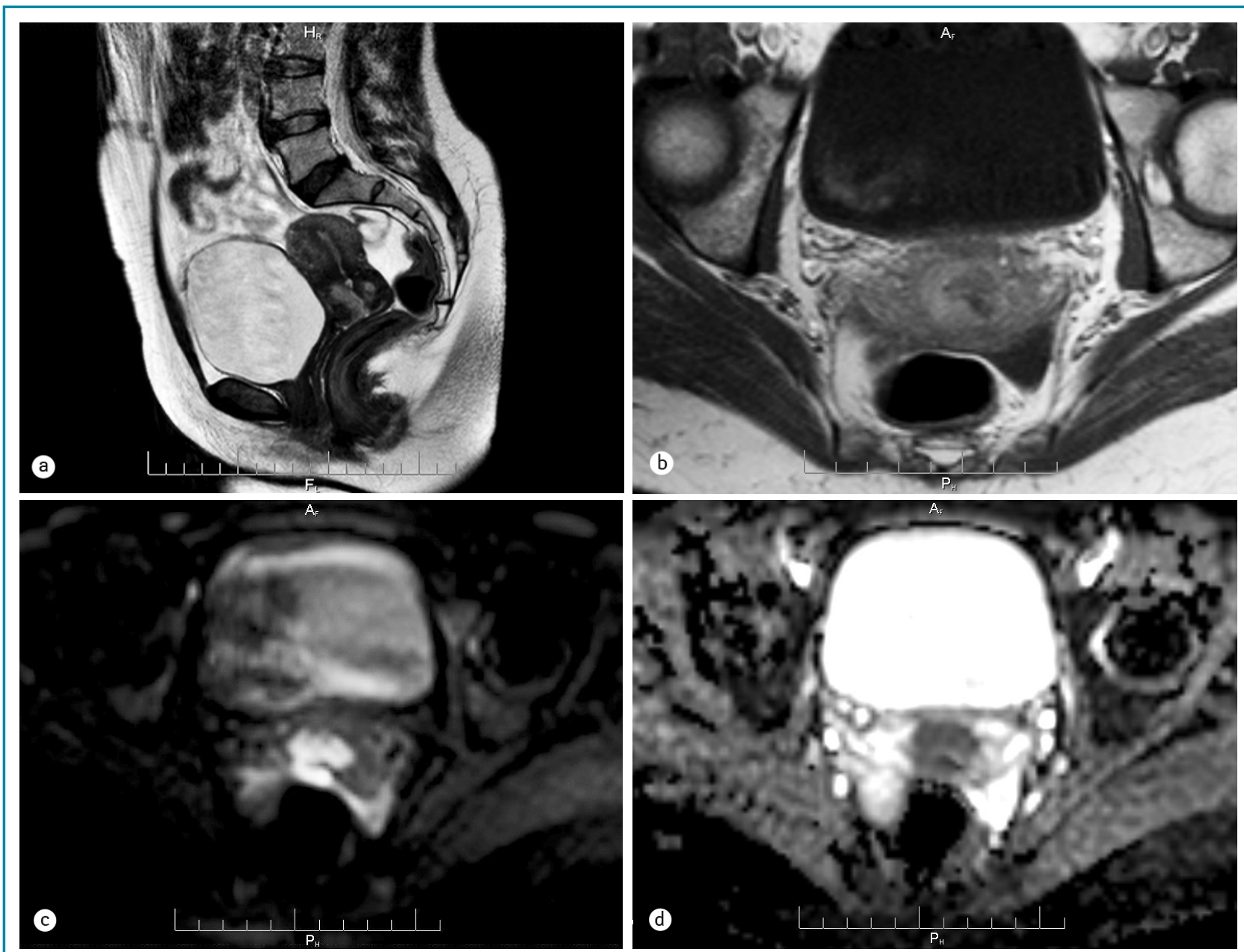

Рис. 1. МРТ таза пацієнтки з РШM T1b без наявності інвазії. На сагітальному T2W зображенні (a) ендофітна пухлина, навколо якої збережений прошарок неураженої строми шийки матки, на постконтрастних сканах (b) було виявлено інтенсивне накопичення контрасту лише в пухлині, при DWI b=0 (c), на ADC-карті $(d)$ зона обмеження дифузії розташовувалася лише в шийці матки, що виключало наявність інвазії в параметрій 
оцінки співвідношення між результатами діагностичних методів та гістологічними результатами було використано метод Пірсона, або $\chi^{2}$, тоді як для оцінки значущості відмінностей між методами непараметричний тест (тест МакНемаpa), $p \leqslant 0,05$ вважали статистично значущим.

\section{РЕЗУЛЬТАТИ}

Серед 62 обстежених хворих на РШМ поширення пухлинного процесу було виявлено при гістопатологічному дослідженні в 11 випадках (у 3 випадках - лише в параметрій, у 8 випадках лише у піхву). У разі клінічно встановленого РШМ Tis - T1а застосування МРТ дозволило виключити невидиму при клінічному дослідженні ендофітну форму інвазивного раку, щоб уникнути проведення розрізу через пухлину під час конізації шийки матки та трахелектомії. Відомо, що стадія Т1а РШМ непомітна на МРТ, однак виключення інвазивної пухлини є важливим для оцінки доцільності органозберігаючих операцій $[5,7]$. У 10 з 11 випадків наявність інвазії була правильно діагностована при всіх послідовностях МРТ. Інвазію пухлини в параметрій визначали як порушення цілісності гіпоінтенсивного кільця периферичної строми шийки матки на T2W, тяжистій пухлинно-параметріальній межі, наявності гіперінтенсивних на T2W пухлинних мас за межами шийки матки в параметрії $[2,7,12,13]$. Після застосування контрастних препаратів пухлинна тканина демонструвала накопичення контрасту. Пухлини з високою клітинністю характеризувалися поєднанням гіперінтенсивності на нативних сканах з високим значенням b та відповідною низькою інтенсивністю на ADC-карті [3, 10] (рис. 1).

У 1-му випадку поширення РШМ не було виявлено в жодній послідовності, оскільки мало місце поверхневе ураження слизової оболонки піхви виразкового характеру. Гіпердіагностика інвазії РШМ при оцінці лише нативних сканів мала місце у 6 пацієнток: у 4 випадках - у параметрій, у $2-$ у піхву. Усі хибнопозитивні результати, отримані за нативних послідовностей, залишалися помилковими після оцінки постконтрастних сканів. Крім того, використання контрастування додало 2 хибнопозитивні результати: в 1 випадку імітувало наявність інвазії параметрія, у 2 - піхви (рис. 2).

Гістологічне дослідження цих пацієнтів виявило лише запальні зміни, некроз та гіперемію тканин, що оточують пухлину. Ці стани імітували пухлинну інвазію $[5,7,10,13]$. Помилкове завищення ступеня інвазії пухлини при оцінці постконтрастних сканів було пов'язане з інтенсивним накопиченням контрастної речовини навколо пухлини внаслідок посилення васкуляризації в тканинах з реактивним запаленням, що може ускладнювати правильну діагностику [13-16].

DWI практично не залежить від васкуляризації. Це допомагає диференціювати висококлітинні пухлини від ділянок запалення з високим вмістом води, які, на відміну від пухлин, мають низьку клітинність і, таким чином, не демонструють обмеження дифузії на DWI $[3,7,10]$. У наших дослідженнях використання DWI дозволило виключити 4 хибнопозитивні результати, отримані за допомогою нативного МРТ. У 2 випадках екзофітні пухлини,
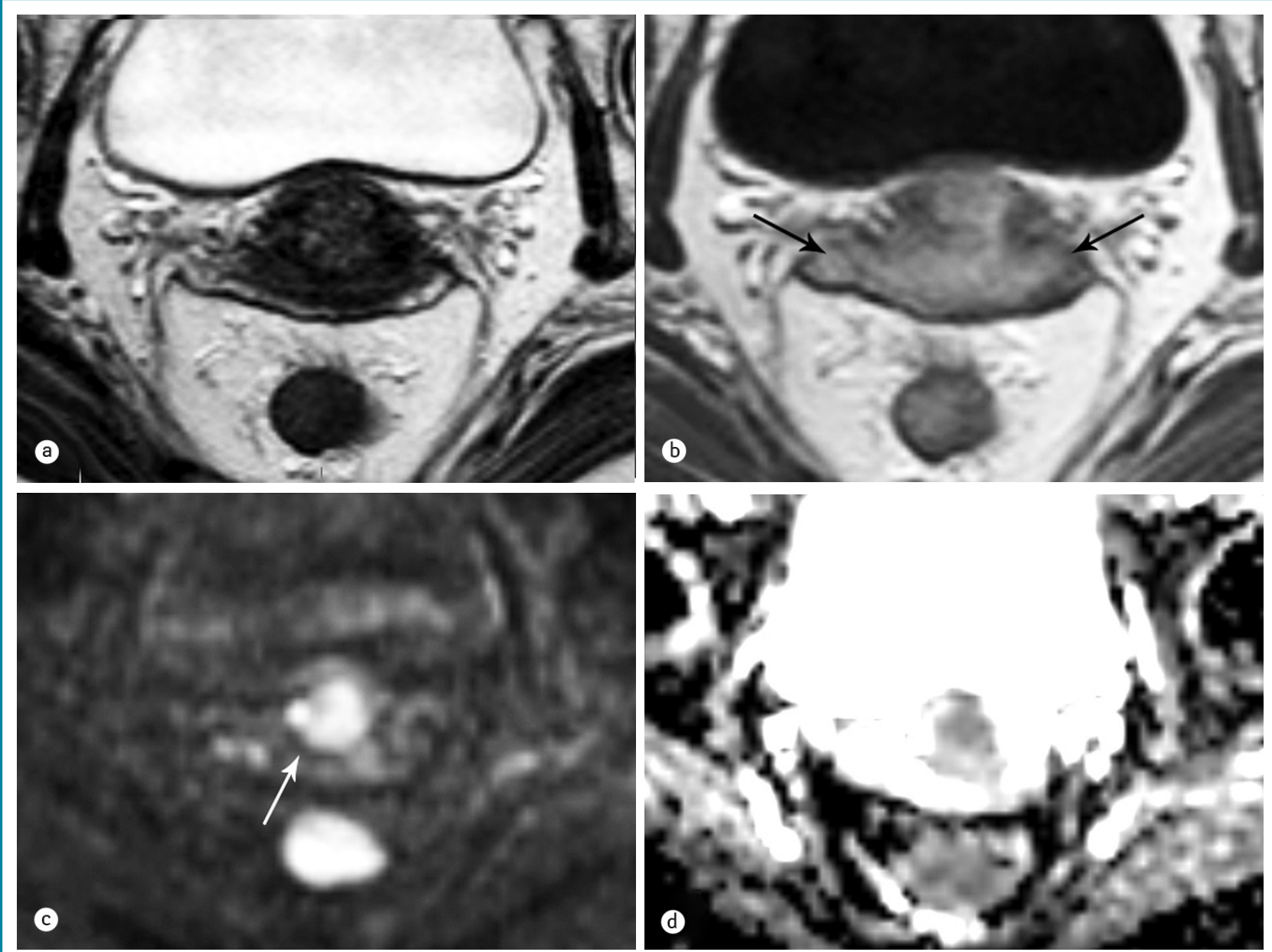

Рис. 2. МРТ таза пацієнтки з РШМ Т2а без інвазії в параметрій. На аксіальних (a) зображеннях Т2W збережений прошарок гіпоінтенсивної строми шийки матки навколо пухлини, що виключало наявність інвазії в параметрії, але постконтрастні скани (b) демонстрували накопичення контрасту в параметрії справа і ліворуч (чорні стрілки), що імітувало інвазію пухлини, але при DWI b=800 c/mм² (c) та ADC-карті $(d)$ зона обмеження дифузії була розташована лише в центральній частині шийки матки (біла стрілка) 


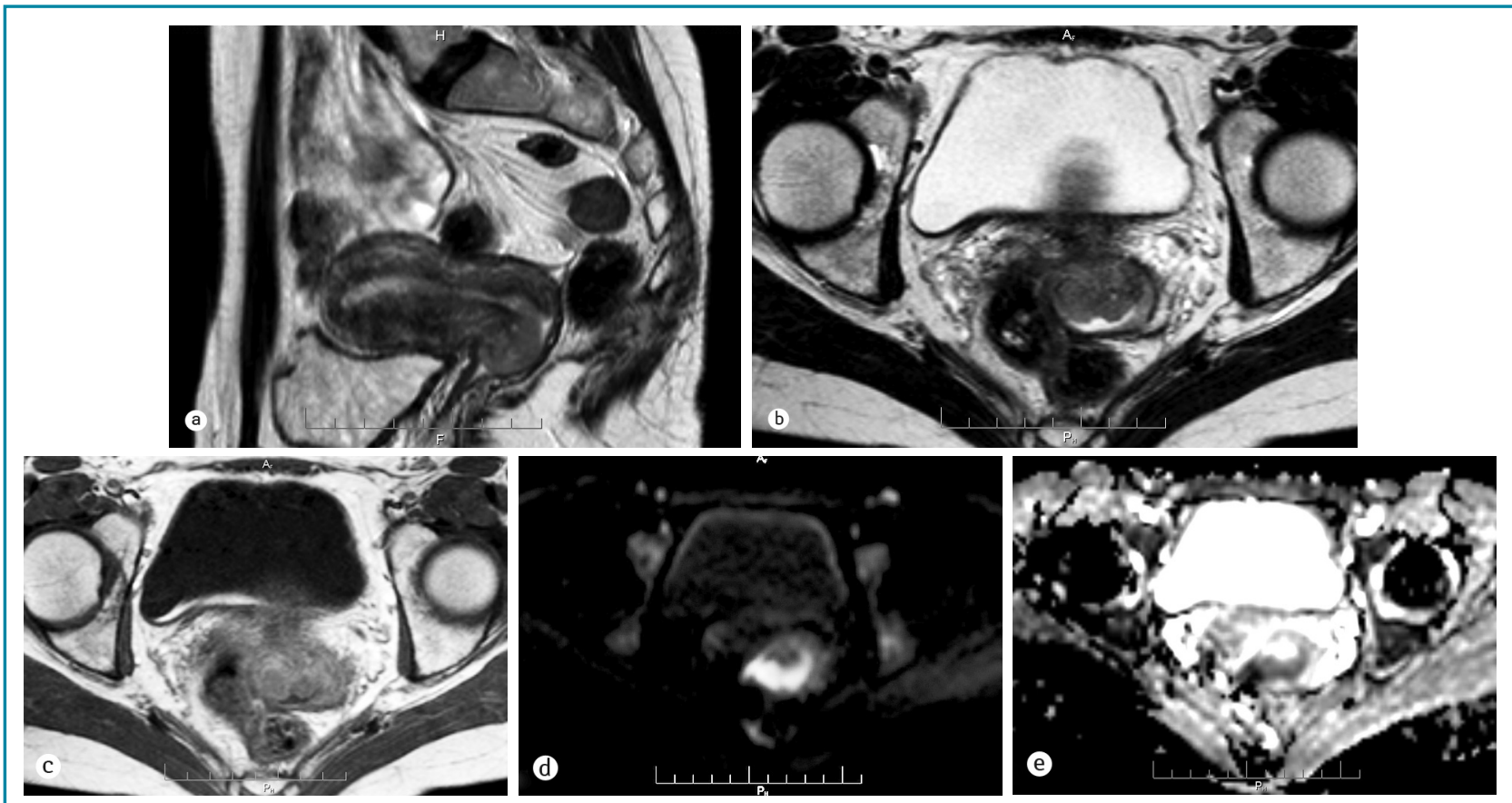

Рис. 3. МРТ таза пацієнтки з РШМ Т1b. Екзофітна пухлина, що прилягає до стінок піхви, представлена на сагітальному скані (a) T2W. На аксіальних (b) зображеннях T2W потовщені стінки піхви гіперінтенсивні, з нерівномірним накопиченням

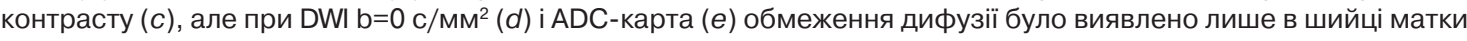
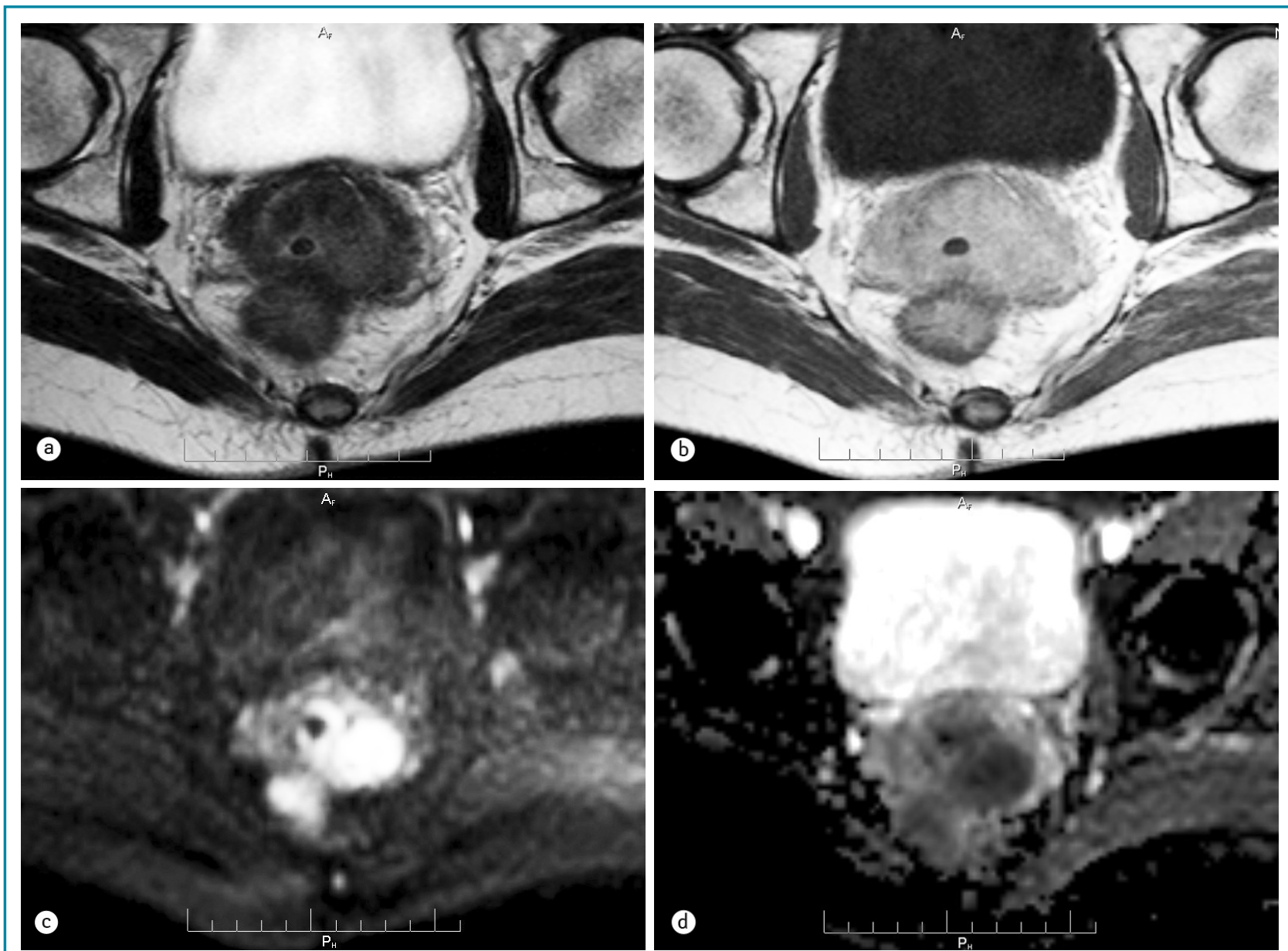

Рис. 4. МРТ таза пацієнтки з РШМ Т2b після неоад'ювантної хіміотерапії. На аксіальних (а) зображеннях Т2W визначали підвищену інтенсивність у верхній третині піхви зліва з інтенсивним накопиченням контрасту (b), що імітувало наявність інвазії у піхву, але при DWI b=800 s/mm ${ }^{2}(c)$ посилення сигналу та симетричне зниження сигналу на ADC-карті $(d)$ виявлено лише в шийці матки. Гістологічне дослідження не виявило пухлинної інфільтрації піхви 


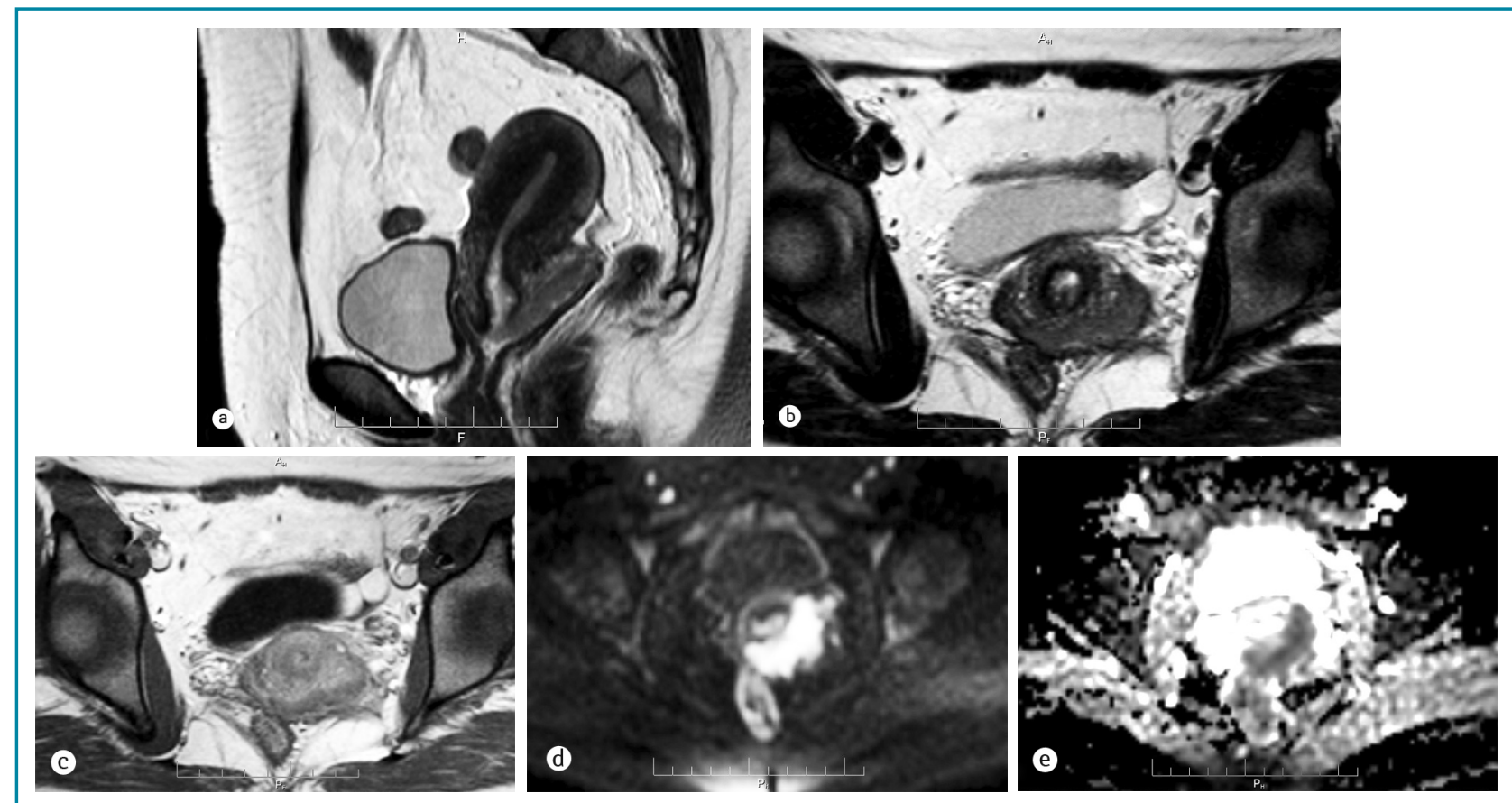

Рис. 5. МРТ таза пацієнтки з РШМ Т1b. На сагітальній (a) та аксіальній (b) Т2W виявлено тяжистий задній контур шийки матки, що супроводжується контрастним підсиленням (b), та ознаками обмеження дифузії поза межами шийки матки на DWI b=800 c/mм ${ }^{2}(c)$ та ADC-карті $(d)$, що імітувало ураження параметрію. Гістологічне дослідження не виявило інвазії, мали місце запальні зміни з масивною лейкоцитарною інфільтрацією.

що виступали в просвіт піхви, щільно прилягали до іiї стінок і розтягували їх. У піхвових стінках, що прилягають до пухлини, розвинувся реактивний набряк, що супроводжувався нечіткістю контурів піхви, підвищенням інтенсивності сигналу при Т2Вт і збільшенням накопичення контрасту, що імітувало пухлинну інвазію, але відсутність обмеження дифузії на DWI в стінках піхви дозволяло виключити наявність інвазії (рис. 3).

У 3 випадках в життєздатних пухлинних тканинах були ділянки реактивного запалення, які також давали сигнал гіперінтенсивності на T2W і демонстрували накопичення контрасту на постконтрастних сканах, що призводило до помилкових результатів. Але використання DWI дозволило диференціювати висококлітинні пухлинні тканини від набряку (рис. 4).

У 2 випадках гіпердіагностика інвазії була наявна в усіх послідовностях. У цих випадках запальні зміни в шийці матки супроводжувалися лейкоцитарною інфільтрацією та некрозом з геморагічними ділянками, що відображалося у вигляді зон підвищеної інтенсивності на нативних та постконтрастних сканах з наявністю обмеження дифузії на DWI (рис. 5).

\section{ОБГОВОРЕННЯ}

Інформативність кожної послідовності МРТ розраховували, виходячи з отриманих результатів (таблиця).

Найбільша кореляція між результатами діагностичних досліджень та післяопераційними даними була у випадку T2W/DWI (значення $\chi^{2}$ Пірсона 43,8 порівняно з 29,6 при нативних МРТ та 24,8 на постконтрастних МРТ).

Позитивна прогностична цінність, чутливість, специфічність та точність нативної МРТ в оцінці інвазії РШМ становили 62,$5 ; 90,9 ; 88,2$ та 88,7\% відповідно. Використання контрастування не підвищило інформативності МРТ $(p>0,05)$ : позитивна прогностична величина, чутливість, специфічність та точність становили 55,5; 90,9; 84,3 та 85,4\% відповідно. Застосування T2W/DWI дозволило зменшити кількість помилково позитивних результатів, що значно підвищило ефективність MPT $(p<0,05)$ : позитивні прогностичні значення, чутливість, специфічність та точність становили 83,$3 ; 90,9 ; 96,0$ та 95,1\% відповідно.
Таблиця. І Інформативність послідовностей MPТ

\begin{tabular}{lcc}
\hline \multicolumn{1}{c}{ Показник } & $\begin{array}{c}\text { Нативні скани } \\
\text { МРт }\end{array}$ & $\begin{array}{c}\text { Постконтраст- } \\
\text { ні скани }\end{array}$ \\
\hline Кількість хворих, $n$ & 62 & 62 \\
Істинно позитивні & 10 & 10 \\
Хибно позитивні & 6 & 8 \\
Істинно негативні & 45 & 43 \\
Хибнонегативні & 1 & 1 \\
Не визначені & 0 & 3 \\
Позитивне прогностичне значення,\% & 62,5 & 55,5 \\
Чутливість, \% & 90,9 & 90,9 \\
Специфічність, \% & 88,2 & 84,3 \\
Точність, \% & 88,7 & 85,4 \\
Х2 , значення Пірсона, $p$ & $29,6<0,001$ & $24,8<0,001$ \\
Тест Мак-Немара 3 двома хвоста- & - & $>0,05$ \\
ми, р (у порівняні з нативним МРТ) & & \\
\hline
\end{tabular}

Обмеження дослідження були такими: невелика кількість спостережень, неоднорідність спостережень (різні стадії захворювання та різні ділянки інвазії пухлини), використання лише якісної, а не кількісної оцінки результатів DWI. Необхідні подальші дослідження для дослідження корисності різних послідовностей МРТ для діагностики РШМ.

\section{висновки}

МРТ - це ефективний метод променевого дослідження для стадіювання РШМ. Найбільш інформативною комбінацією для оцінки місцевого поширення пухлинного процесу у хворих з верифікованим РШМ є поєднання нативної послідовності з DWI, тому доцільно включати DWI в протокол магнітнорезонансного дослідження цих пацієнток.

\section{СПИСОК ВИКОРИСТАНОÏ ЛІТЕРАТУРИ}

1. Федоренко, З.П., Гулак, Л.О., Михайлович, Ю.Й., Горох, Є.Л., Рижов, А.Ю., Сумкіна, О.В., \& Куценко, Л.Б. (2020). Рак в Україні, 2018-2019. Захворюваність, смертність, показники діяльності онкологічної служби/гол. ред. О.О. Колеснік. Бюлетень Національного канцер-реєстру України, 21, 101.

2. Fields, E.C., \& Weiss, E. (2016). A practical review of magnetic resonance imaging for the evaluation and management of cervical cancer. Radiation Oncology, 11,15. doi: 10.1186/s13014-016-0591-0.

3. Dappa, E., Elger, T., Hasenburg, A. Düber, Ch., Battista, M.J., \& Hötker, A.M. (2017). The value of advanced MRI techniques in the assessment of cervical cancer: a review. Insights into Imaging, 8(5), 471. doi: 10.1007/s13244-017-0567-0.

4. Bhatla, N., Berek, J.S., Fredes, M., Denny, L.A., Grenman, S., Karunaratne, K., ... Sankaranarayanan, R. (2019). Revised FIGO staging for carcinoma of the cervix uteri. International Journal of Gynecology \& Obstetrics, 145,129-135. doi: 10.1002/ijgo.12749. 
5. Patel, S., Liyanage, S.H., Sahdev, A., Rockall, A.G., \& Reznek, R.H. (2010). Imaging of endometrial and cervical cancer. Insights into Imaging,1(5-6), 309-328. doi: 10.1007/s13244-010-0042-7.

6. Togashi, K., Nishimura, K., Sagoh, T., Minami, S., Noma, S., Fujisawa, I. Konishi, I. (1989). Carcinoma of the cervix: staging with MR imaging. Radiology; 171 245-51. doi: 10.1148/radiology. 171.1.2928532.

7. Mahajan, M., Kuber, R., Chaudhari, K.R., Chaudhari, P., Ghadage, P. \& Naik, R. (2013). MR imaging of carcinoma cervix. Indian Journal of Radiology and Imaging, 23, 247-252. doi: 10.4103/0971-3026.120257.

8. O'Connor, J.P., Tofts, P.S., Miles, K.A., Parkes, L.M., Thompson, G., \& Jackson, A. (2011). Dynamic contrast-enhanced imaging techniques: CT and MRI. The British Journal of Radiology, 84,112-120. doi: $10.1259 / \mathrm{bjr} / 55166688$.

9. Rogosnitzky, M., \& Branch, S. (2016). Gadolinium-based contrast agent toxicity: a review of known and proposed mechanisms. Biometals, 29, 365-376. doi: 10.1007/s10534-016-9931-7.

10. Lucas, R., Lopes, D.J, \& Cunha, T.M. (2015). Added value of diffusion-weighted MRI in detection of cervical cancer recurrence: comparison with morphologic and dynamic contrast-enhanced MRI sequences. Diagnostic and Interventional Radiology, 21,368-375. doi: 10.5152/dir.2015.14427.

11. Nougaret, S., Tirumani, S.H., Addley, H., Pandey, H., Sala, E., \& Reinhold, C. (2013). Pearls and pitfalls in MRI of gynecologic malignancy with diffusion-weighted technique. American Journal of Roentgenology, 200, 261-276. doi: 10.2214/AJR.12.9713.

12. Kaur, H., Silverman, P.M., lyer, R.B., Verschraegen, Cl.F., Eifel, P.J., \& Charnsangavej, Ch. (2003). Diagnosis, staging and surveillance of cervical carcinoma. American Journal of Roentgenology, 180, 1621-1632. doi: 10.2214/ajr.180.6.1801621.

13. Sala, E., Wakely, S., Senior, E., \& Lomas, D. (2007). MRI of malignant neoplasm of the uterine corpus and cervix. American Journal of Roentgenology, 188, 1577-1587. doi: 10.2214/AJR.06.1196.

14. Rizzo, S., Calareso, G., Maccagnoni, S., Alessio Angileri, S. Landoni, F., Raimondi, S., ... Bellomi, M. (2014). Pre-operative MR evaluation of features that indicate the need of adjuvant therapies in early stage cervical cancer patients. A single-centre experience. European Journal of Radiology, 83(5), 858-864. patients. A single-centre experience.
doi: $10.1016 / \mathrm{j}$.ejrad.2014.01.029.

15. Vincens, E., Balleyguier, C., Rey, A., Uzan, C., Zareski, E., Gouy, S., Morice, $\mathrm{Ph}$. (2008). Accuracy of magnetic resonance imaging in predicting residual disease in patients treated for stage IB2/II cervical carcinoma with chemoradiation therapy: correlation of radiologic findings with surgicopathologic results. Cancer, 113 , 2158-2165. doi: $10.1002 /$ cncr.23817.

16. Rauch, G.M., Kaur, H., Choi, H., Ernst, R.D., Klopp, A.H. Boonsirikamchai, P., ... Marcal, L.P. (2014). Optimization of MR imaging for pretreatment evaluation of endometrial and cervical cancer. Radiographics, 34(4),1082-1098 doi: $10.1148 / \mathrm{rg} .344140001$

\section{Лучевая диагностика для оценки локального распространения опухоли у больных раком шейки матки}

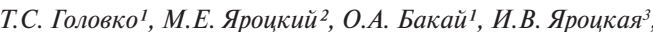
Н.Ф. Лигирда ${ }^{1}$

Национальный институт рака, Киев 2000 “Академический медицинский центр", Киев ${ }^{3}$ Национальная медицинская академия последипломного образования имени П.Л. Шупика, Киев

Резюме. При верифицированном раке шейки матки (РШМ) основной задачей лучевого исследования является оценка распространения опухолевого процесса, поскольку это в корне влияет на выбор тактики лечения и прогноз заболевания. Целью исследования было оптимизировать магнитно-резонансное исследование для определения местного распространения опухолевого процесса у пациентов с РШМ путем сравнения полезности различных последовательностей магнитно-резонансной томографии. Объект и методы исследования. 62 пациента с РШМ, которые проходили обследование и лечение в Национальном институте рака. Структура распределения по стадиям TNM: Tis - y $2(3,2 \%)$, T1a1 - y $3(4,8 \%)$, T1a 2 - у $2(3,2 \%)$ T1b1 - y $17(27,5 \%)$, T1b2 - y $16(25,9 \%)$, T2a - y $19(30,6 \%)$ T2b - у 3 (4,8\%) пациенток. Морфологическая структура РШМ: у $54(87,1 \%)$ - плоскоклеточный рак, у $6(9,7 \%)-$ аденокарцинома, у 2 (3,2\%) - адено- плоскоклеточный рак. Всем больным выполнено оперативное удаление опухоли. 3 пациентки с РШМ Т1b2, 18 - с Т2А и 3 - с Т2b получили курс неоадъювантной химиотерапии. Пациенткам проводили магнитно-резонансную томографию на томографе Philips (Intera) 1,5 Т с применением контрастного усиления и диффузионно-взвешенной визуализации (Diffusion-weighted imaging - DWI). Результаты лучевой оценки распространения опухолевого процесса сопоставлены с данными морфологического исследования. Результаты. Определена диагностическая эффективность методов лучевого исследования для оценки местного распространения опухоли у больных РШМ. Ошибочное завышение степени распространения опухолевого процесса было обусловлено интенсивным накоплением контрастного вещества тканями вокруг опухоли вследствие реактивного воспаления. Использование DWI позволило уменьшить количество ошибочно положительных результатов и значительно повысило эффективность магнитно-резонансной томографии $(\mathrm{p}<0,05)$ : положительная прогностическая величина, чувствительность, специфичность и точность составили 83,3; 90,9; 96,0 и 95,1\% соответственно. Bыводы. Наиболее информативной комбинацией для оценки местного распространения опухолевого процесса у больных с верифицированным РШМ является сочетание нативной последовательности с DWI, поэтому целесообразно включать DWI в протокол магнитно-резонансного исследования этих пациенток.

Ключевые слова: рак шейки матки; местное распространение опухолевого процесса; магнитно-резонансная томография; контрастное усиление; диффузионно-взвешенные изображения.

\section{Radiation diagnosis for assessment of local tumor distribution in patients with cervical cancer}

\section{T.S. Golovko ${ }^{1}$, M.E. Yarotsky², O.A. Bakay ${ }^{1}$, I.V. Yarotska ${ }^{3}$,} N.F. Ligirda

'National Cancer Institute, Kyiv ${ }^{2}$ Limited liability company Academic Medical Centre, Kyiv ${ }^{3}$ Shupik National Medical Academy of Postgraduate Education, Kyiv

Abstract. With verified cervical cancer, the main task of radiation studies is tumor process spread evaluation since this has a profound effect on the treatment tactics choice and prognosis. Aim of study was Magnetic Resonance study optimizing for tumor process local spread evaluation in patients with CC via comparing the usefulness of different Magnetic Resonance Imaging sequences. Material and methods: 62 patients with Cervical cancer were examined by Magnetic Resonance Imaging on tomograph 1,5 T using contrast enhancement and Diffusion-weighted imaging (DWI). Pre-operation radiation diagnostics results of tumor spread were compared with surgical and pathologic data. Results. The diagnostic efficiency of different methods of radiation testing for the evaluation of local tumor distribution in patients with Cervical cancer was determined. Using contrast didn`t increase informative Magnetic Resonance Imaging in evaluation of local tumor distribution. False overstatement degree distribution tumor process was due to intensive accumulation contrast substance around the tumor in consequence of reaction inflammation. Use of DWI allowed to reduce the number of false positive results, which significantly increased the efficiency of Magnetic Resonance Imaging $(\mathrm{p}<0.05)$ : the positive predictive value, sensitivity, specificity and accuracy were 83,$3 ; 90,9 ; 96,0$ and $95,1 \%$ respectively. Conclusions. The most informative combination for assessing the local spread of the tumor process in patients with verified cervical cancer is the combination of the native sequence with DWI, so it is advisable to include DWI in the Magnetic Resonance protocol of these patients.

Key words: cervical cancer; local tumor invasion; radiation diagnostics; Magnetic Resonance Imaging; contrast-enhanced images; Diffusion-weighted imaging.

Aдреса:

Бакай Ольга Олексіївна

О3022 Киів, вул. Ломоносова, 33/43

Національний інститут раку

E-mail: bakaiolga1050@gmail.com 